\title{
Motywy najbliższe w twórczości Józefa Panfila
}

omaszów Mazowiecki to miejsce szczególnie bliskie Józefowi Panfilowi, jednemu z najaktywniejszych twórczo współczesnych polskich malarzy. Tam artysta przyszedł na świat w 1958 roku, tam mieszkał przez 15 lat po

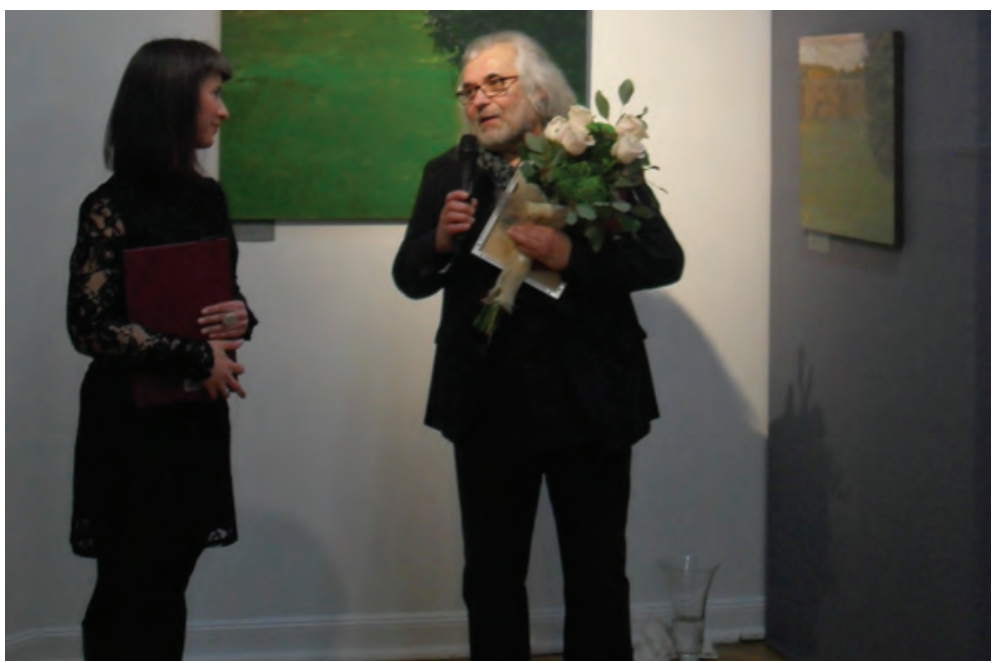

\footnotetext{
1. Dyrektor Dorota Bill-Skorupa i Józef Panfil podczas wernisażu wystawy „Motywy najbliższe" w Muzeum im. Antoniego hrabiego Ostrowskiego w Tomaszowie Mazowieckim w grudniu 2018 roku. Fot. M. Nowakowska
}

ukończeniu studiów w Państwowej Wyższej Szkole Sztuk Plastycznych w Łodzi, tam też malował widoki z okna (pierwszej) pracowni. W Muzeum im. hr. Antoniego Ostrowskiego w Tomaszowie Mazowieckim artysta miał dotąd cztery wystawy indywidualne, z których ostatnia, czynna na przełomie grudnia 2018 i stycznia 2019 roku, miała wymiar szczególnie osobisty. Józef Panfil świętował nią bowiem swoje 60. urodziny i na tę okoliczność zaprezentował najstarsze z zachowanych prac: akwarele i szkice węglem z czasów nauki w Liceum Sztuk Plastycznych w Łodzi (którego jest ambasadorem) i studiów, wspominane widoki z okna tomaszowskiej pracowni oraz pejzaże miejsc szczególnie mu bliskich - Smardzewic i Białobrzegów - dopełnione dziełami najnowszymi, również przedstawiającymi rodzinne strony artysty oraz inne polskie krajobrazy. 
Ten fragmentaryczny i kameralny pokaz rysunkowej i malarskiej twórczości potwierdził źródła inspiracji, jakimi są dla artysty niezmiennie od prawie czterech dekad rodzinne strony: wnętrza i bryła barokowego kościoła św. Anny i klasztoru ojców franciszkanów w Smardzewicach, panorama i kadry Smardzewic ze szczególnym naciskiem na własną posesję, na której się wychowywał i na której postawił dom i obecną pracownię. Bezustannie okrywając urodę i tajemnice tych miejsc, artysta zaskakuje widza wrażliwością wnikliwego obserwatora natury, uwiecznianej o różnych porach dnia i roku farbami olejnymi i akrylowymi na różnych formatach i podobraziach, oryginalnie kadrowanej. Józef Panfil jest bowiem mistrzem w wynajdywaniu subtelnych niuansów budujących nastrój krajobrazu, zazwyczaj lirycznego i nostalgicznego, czemu sprzyjają takie sytuacje jak wschody i zachody słońca nad panoramą smardzewickich dachów, wiosenne i zimowe przesilenia, pełnie księżyca nad otuloną śniegiem zabudową wsi, skąpane w letnim upale stodoły, dodajmy - oglądane z różnych perspektyw, malowane z wielką dbałością o kompozycję, która zawsze była niezwykle ważna dla artysty. To pokłosie łódzkiej edukacji, a zwłaszcza dyscypliny formalnej w myśleniu o obrazie, tzw. konstrukcji dzieła, które - pomimo impresyjności - zawsze ma u artysty wewnętrzną logikę. Najlepiej pokazują to jego szkice, zarówno te wczesne, w których kadrował węglem bryłę i wnętrze smardzewickiego kościoła i klasztoru oraz kościoła w pobliskich Białobrzegach, jak też licealne akwarele dokumentujące kształtowanie się talentu młodego artysty. Warto dodać, że od 2001 roku Józef Panfil prowadzi książkowe szkicowniki, w których ołówkiem notuje swoje wrażenia z podróży i plenerów, aby na ich bazie już w pracowni tworzyć kolejne malarskie cykle. Rysunki te są interesującym studium procesu badania formy i struktury krajobrazu, przekładającym się na przemyślaną, wyważoną w każdym szczególe kompozycję. W szkicach z natury artysta eksperymentuje $\mathrm{z}$ natężeniem linii, spiętrzaniem planów, walorowym budowaniem głębi obrazu - tym ciekawszy jest efekt uzyskiwany w jego dziełach malarskich, zwłaszcza tych z ostatnich lat, chyba najdojrzalszych formalnie.

Wystawa w Tomaszowie pozwalała prześledzić owo wypracowywanie własnego stylu malarskiego Józefa Panfila - od syntetyzowania form i spłaszczania przestrzeni w widokach z pracowni z lat 1987-1997 przy zawężeniu palety do przełamanych brązów, beży, czerni i bieli obwiedzionych mocnym konturem, poprzez badanie niuansów świetlistego koloru w pracach coraz bardziej realistycznych, choć zawsze subtelnie rozwibrowanych plamami świetlistego, ciepłego koloru, aż po ostatnie, najnowsze motywy ze Smardzewic z 2019 roku, w których pierwszoplanowa soczysta zieleń trawy malowana mocnymi impastami odmaterializowuje przestrzeń rodzinnego podwórza, nie pozbawiając go wszakże lirycznej, nastrojowej aury poprzez dodanie partii typowo „polskiego” nieba - z wyłaniającym się zza chmur księżycem lub obłokami. Tak malowany pejzaż zaczyna nabierać znaczeń symbolicznych, 


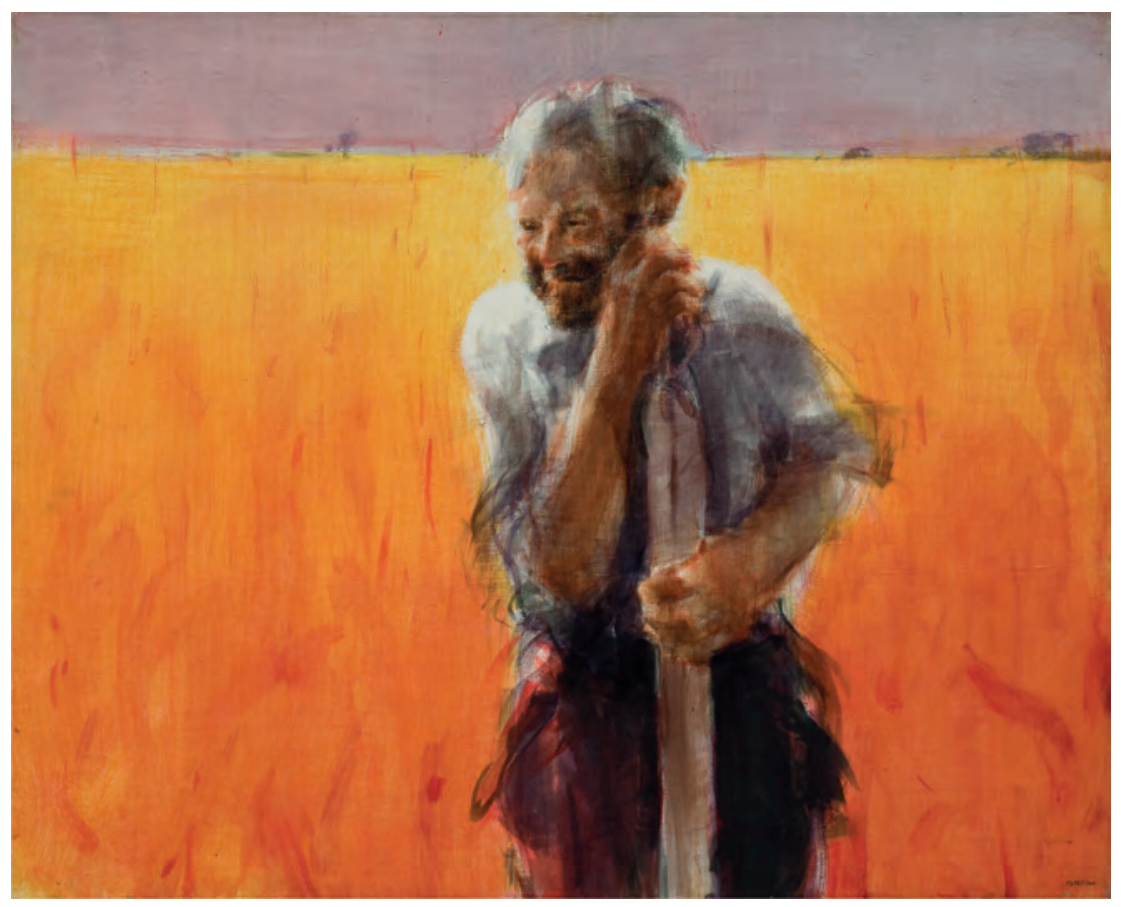

2. Józef Panfil, Horyzont X, 1990, olej, płótno, 81 × $100 \mathrm{~cm}$

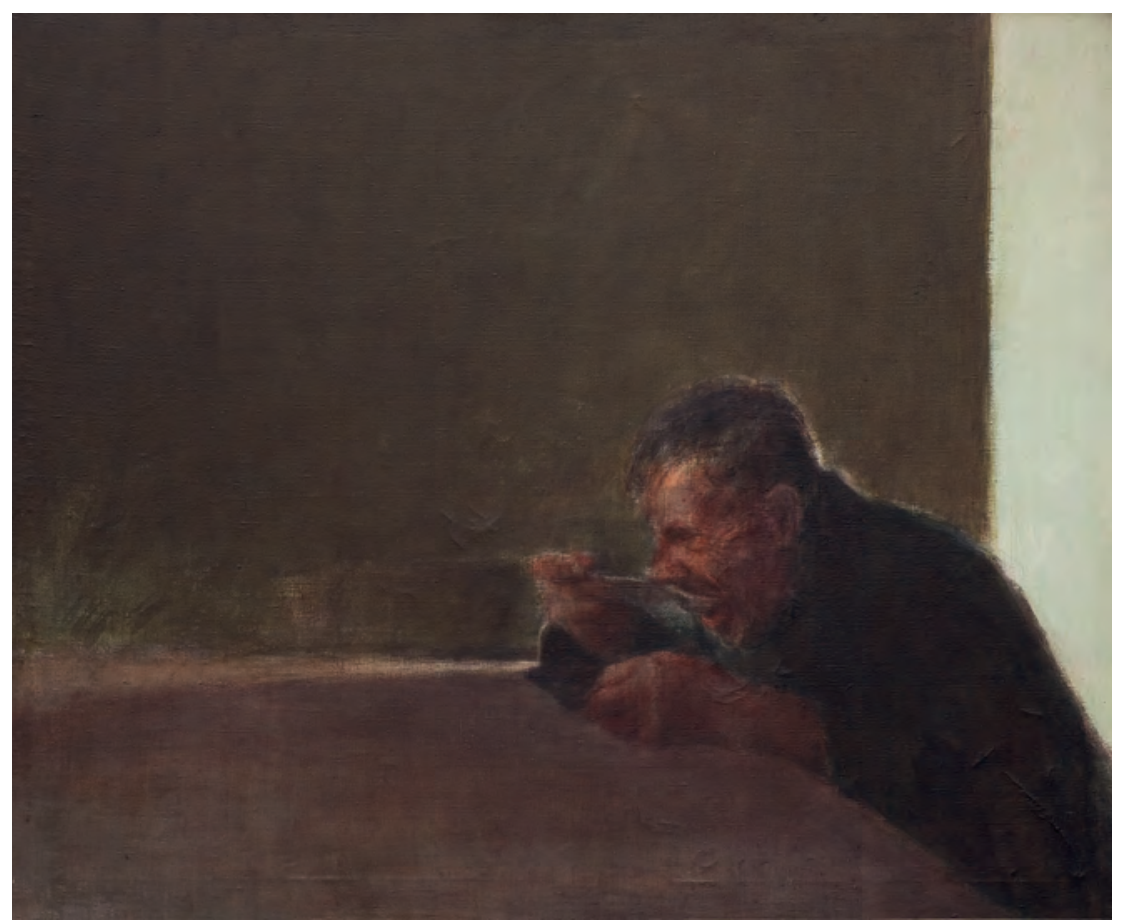

3. Józef Panfil, Przy stole, akryl, 81 × 100 cm 
w których Smardzewice stają się dla autora prac epicentrum świata, kwintesencją tego, co polskie, rodzime, osadzone w tradycji.

Bo też w tradycji polskiego pejzażu należy szukać odniesień, często podświadomych, dla twórczości Józefa Panfila, wydającego się z dzisiejszej perspektywy historii sztuki naturalnym kontynuatorem takich Mistrzów rodzimego pejzażu jak Aleksander Gierymski, Józef Chełmoński, Jan Stanisławski, Julian Fałat czy Edward Okuń. Z impresjonizmem i młodopolskim symbolizmem łączy go nie tylko doskonały warsztat i wielka kultura malarska, wrażliwość kolorysty czułego na współzależności światła i barwy, szlachetna prostota w syntetyzowaniu motywów i dbałość o oryginalność kompozycji, ale przede wszystkim dążenie do uzyskania w obrazie wewnętrznej harmonii, wynikającej z chęci uchwycenia uniwersalnej prawdy o świecie. Z tym z kolei wiąże się pełna pokory i szacunku postawa artysty wobec natury.

Zdaniem Łukasza Kossowskiego, autora wstępu do katalogu indywidualnej wystawy Józefa Panfila prezentowanej w Galerii Kordegarda w Warszawie latem 2018 roku, artysta ten nie tyle uwiecznia, co „opowiada” polski pejzaż, odwołując się do treści literackich i osobistych przeżyć, tworząc swoiste „haiku na cześć natury”. Równie trafna jest opinia Wiesława Ochmana, światowej sławy tenora, prywatnie wielbiciela i kolekcjonera prac Józefa Panfila:

Panfil nie usiłuje tworzyć czegoś co jest poza prawdą. Zachwyt nad otaczającą nas przyrodą jest wystarczającym powodem, aby zapisać swoje wrażenie i do tego nie są mu potrzebne żadne ideologie ani manifesty malarskie (...). Przyroda staje się w pracach Panfila pretekstem do tworzenia nastroju, nie przy pomocy czysto przyrodniczych elementów, ale poprzez malarskie uzasadnienie ich obecności w obrazie. Maluje doznania, a nie przedmiotowość tematu (...), raczej kontempluje rzeczywistość, niż ją tworzy.

Doskonale oddają te słowa obrazy z cyklu Motyw z Lubiatowa z 2017 roku - kameralne widoki dostojnych stogów siana pokazanych na tle zmieniającego się w każdym ujęciu nieba: raz zasnutego mgłą, to znów skąpanego w poświacie zachodzącego lub wschodzącego słońca, przykryte śniegiem lub wysuszone upalnym wiatrem. Prosty z pozoru motyw urasta tu do rangi symbolu cykliczności i trwania przyrody, a zarazem jest doskonałym pretekstem do ciekawych rozwiązań formalnych, zwłaszcza jeśli chodzi o niuanse kolorystyczne w obrębie bieli, błękitów i brązów, z których Józef Panfil wydobył maksimum walorowych jakości.

Zaprezentowane w Tomaszowie Motywy z Lubiatowa były ciekawym dopowiedzeniem fascynacji artysty rodzimym pejzażem, zwłaszcza w jego najbardziej charakterystycznym, nizinnym wydaniu, jakże typowym dla mazowieckiej równiny z której pochodzi autor prac. Różnorodne formaty eksponowanych dzieł dowiodły zaś, że Panfil dobrze czuje się nie tylko w miniaturach, wymagających warsztatowej 
biegłości i syntetyzowania, ale też w średnim i większym formacie, w tym kwadratu, dającym pretekst do eksperymentowania z przestrzenią.

Na wystawie zabrakło portretów wuja Stanisława z lat 1996-2001, martwych natur oraz pejzaży z południa Europy: Grecji, Chorwacji, Włoch, Hiszpanii i Francji, gdzie artysta wyjeżdża na plenery od 1994 roku, malując przesycone słońcem mariny, weduty, antyczne ruiny i cyprysy. Są one oczywiście ważnym dopowiedzeniem twórczości Józefa Panfila, także jeśli chodzi o doniesienia do historii sztuki, z której artysta oczywiście czerpie, ale też dodaje własne malarskie przemyślenia i formalne jakości. Tytułowe motywy najbliższe, będące główną osią wystawy, wskazały jednak na najważniejsze i niezmienne źródła jego inspiracji, jakimi są rodzinne strony z ich wiejską zabudową, zabytkami i swojską przyrodą, tak bardzo osadzonymi w tradycji polskiego pejzażu. Artysta świadomie rezygnuje z postaci ludzi i zwierząt, unika też elementów będących przejawami współczesnej cywilizacji, skupiając się na tym, co ponadczasowe, ale też typowe dla polskiej wsi. Położone siedem kilometrów od Tomaszowa Mazowieckiego Smardzewice, niewielka, bo niespełna dwutysięczna miejscowość nad Zalewem Sulejowskim, urastają w pracach Józef Panfila do rangi najbardziej malowniczej i charakterystycznej dla rodzimego krajobrazu polskiej wsi, zatopionej w przeszłości, a jednocześnie uosabiającej trwanie i odradzanie się przyrody wraz z każdą kolejną porą dnia i roku. Swoiste archaizowanie Motywów ze Smardzewic, powracanie do tych samych ujęć i widoków, różniących się czasami tylko kadrem lub kolorystyką, raz jeszcze podkreśla głęboko humanistyczną postawę Józefa Panfila, odnajdującego w naturze niezmienne prawdy i zasady, trwałość i ciągłość procesów witalnych, ale też zgodę na przemijanie, rozumiane jako naturalny etap naszej egzystencji.

Nie określiłabym go natomiast „malarzem zmierzchu ludzkiego życia” - choć namalował wiele nastrojowych i doskonałych warsztatowo zachodów słońca. W jego pejzażach, zwłaszcza polskich, jest melancholia i zaduma nad ludzkim życiem, lecz również afirmacja i fascynacja jego biologicznością, wiara w trwanie i odradzanie, którego dowodem jest natura. Artysta jest kolejnym wielkim piewcą urody polskiego krajobrazu, a wiele jego prac z pewnością przejdzie do kanonu tego gatunku - wciąż cieszącego się wielkim zainteresowaniem kolekcjonerów, galerii i muzeów, a przede wszystkim wielbicieli dobrej sztuki, którzy zapewniają wysoką frekwencję na wystawach prac Józefa Panfila.

Najbliższą okazją do spotkania z tą imponującą warsztatowo, dającą wiele okazji do wzruszeń estetycznych oraz pretekstów do refleksji sztuką będzie wystawa w Galerii Kobro w Akademii Sztuk Pięknych w Łodzi, przygotowywana na inaugurację roku akademickiego 2019/2020 w październiku br. Artysta planuje pokazać na niej prace najciekawsze i najlepsze swoim zdaniem, z różnych okresów twórczości, w tym najnowsze rysunki - podobno portrety. To bardzo obiecująca wiadomość, zważywszy na przejmujące portrety wuja Stanisława z lat 80. i 90. XX wieku 
TECHNE

T E X N H

SER IA NOWA

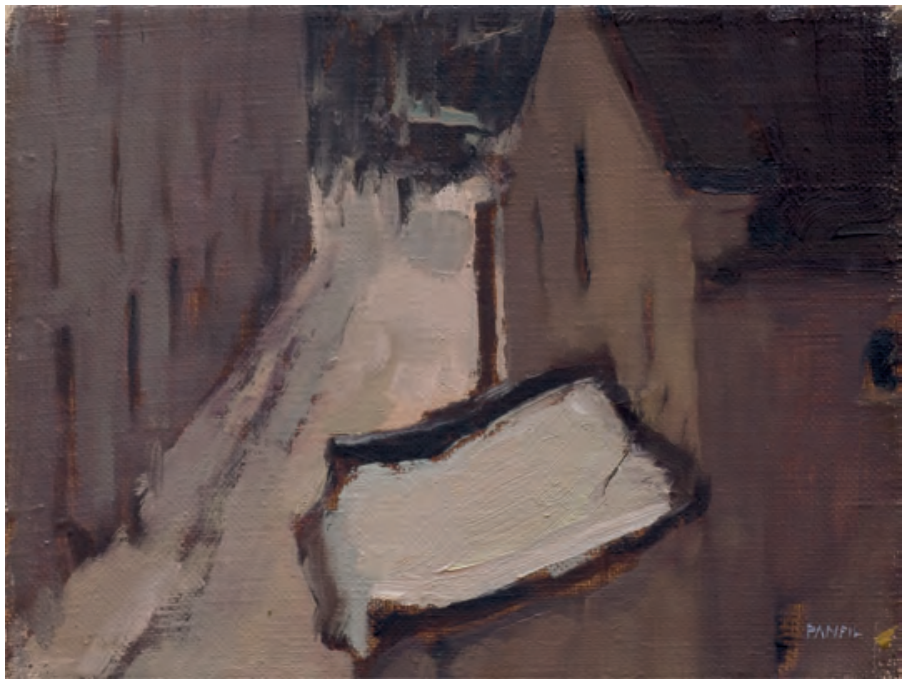

4. Józef Panfil, Widok z okna pracouni, 1994, olej, płótno, 18 × 24 cm

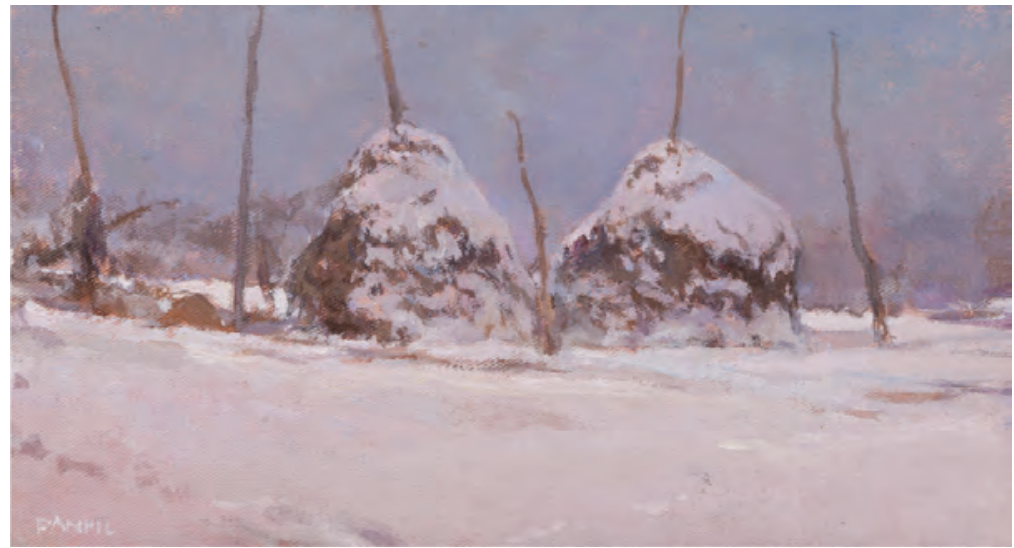

5. Józef Panfil, Motyw z Lubiatowa, 2017, akryl, płyta 18 × 33 cm

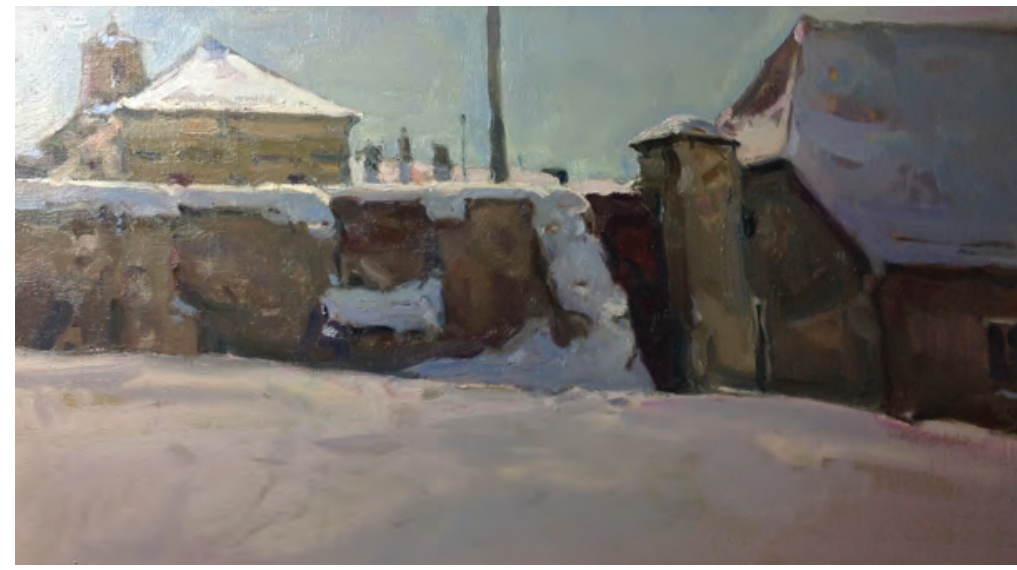

6. Józef Panfil, Motyw z Tomaszowa Mazowieckiego, 2018 
- zarówno rysunkowe studia portretowe węglem, kredką i pastelami, jak i wielkoformatowe obrazy olejne i akrylowe na płótnach, w tym sugestywne dyptyki z cyklu Horyzont. Panfil dał w nich popis wirtuozerii warsztatowej, tworząc niepokojące studia psychologiczne modela - wiejskiego filozofa uosabiającego prostotę i prawdę, zadumę, radość i smutek nad ludzkim losem.

Po śmierci Stanisława artysta długo nie mógł znaleźć kolejnego modela, któremu mógłby zajrzeć w głąb duszy i w ten sposób opowiedzieć kolejną wartościową historię o człowieku. Miejmy zatem nadzieję, że w łódzkiej ASP znów objawi się nam Panfil-portrecista obok wybitnego pejzażysty, a studenci będą mieli okazję do kontaktu z wartościową sztuką. Dodajmy - ze sztuką zbierającą ostatnio zasłużone laury i wyróżnienia, z których wymienić należy Srebrny Medal Zasłużony Kulturze Gloria Artis wręczony artyście przez Ministra Kultury i Dziedzictwa Narodowego prof. Piotra Glińskiego 12 lipca 2018 roku oraz udział obrazu Nadzieja z 1989 roku w wystawie „Znaki wolności. O trwaniu polskiej tożsamości narodowej” przygotowanej przez Zamek Królewski w Warszawie z okazji 100-lecia odzyskania przez Polskę Niepodległości w 2018 roku (czynna od 10 listopada 2018 do 31 marca 2019). Praca ta znalazła się w gronie 500 obiektów, w tym arcydzieł polskiej sztuki autorstwa m.in. Jana Matejki, Jacka Malczewskiego, Maksymiliana Gierymskiego, Brunona Schulza, Zofii Stryjeńskiej, Wojciecha Weissa, Krzysztofa Kamila Baczyńskiego, Jana Lebensteina, Władysława Hasiora, Edwarda Dwurnika, odnoszących się do konkretnych wydarzeń historycznych, zjawisk i ludzkich postaw istotnych dla kształtowania się polskiego patriotyzmu. I taki też wymiar ma sztuka Józefa Panfila - prostymi środkami, bez patosu i górnolotnych tematów pokazująca piękno polskiego pejzażu.

\section{Bibliografia}

Józef Panfil malarstwo małe studia pejzażowe z lat 1989-1998, kat. wystawy objazdowej, Biuro Wystaw Artystycznych w Piotrkowie Trybunalskim.

Józef Panfil Malarstwo / Paintings 1985-2010, kat. wystawy, red. Józef Panfil i Kamila MajCHRZYCKA, Muzeum Miasta Łodzi, Łódź 2010.

Józef Panfil Malarstwo i rysunek z lat 1979-2017, kat. wystawy, red. Monika NowakowsKA, Miejska Galeria Sztuki w Łodzi, Łódź 2017.

Malarstwo Józefa Panfila, czyli dowód na istnienie świata, kat. wystawy, red. ŁukAsz Kossowski, Kordegarda Galeria Narodowego Centrum Kultury, Warszawa 2018. 